\title{
Effect of Plasma Treatment on Seed Crop Characters of Okra [Abelmoschus esculentus (L.) under Field Conditions
}

\author{
Ravinder Kumar ${ }^{1}$, Ashok K. Thakur', Amit Vikram², A. Vaid ${ }^{3}$ and R. Rane ${ }^{3}$ \\ ${ }^{1}$ Dept. of Seed Science and Technology, ${ }^{2}$ Dept. of Vegetable Science, Dr. Y. S. Parmar \\ University of Horticulture and Forestry, Solan, Himachal Pradesh (173 230), India, ${ }^{3}$ FCIPT, \\ Institute for Plasma Research, Gandhinagar, Gujarat (382 044), India
}

*Corresponding author

\begin{abstract}
A B S T R A C T
This study investigated the effect of cold plasma treatment on seed parameters of Okra [Abelmoschus esculentus (L.)] cultivar P-8. The experiment comprising of seeds of two different age viz., 'A1' (One year old seed) and 'A2' (Two year old seed) and seven

Keywords

Okra, ageing, Seed treatment, Cold plasma, Seed yield

Article Info

Accepted:

10 November 2018

Available Online:

10 December 2018 plasma treatment using glow discharge technique at FCIPT, Institute for Plasma Research, Gandhinagar, Gujarat, India. The seeds were pre-treated with power of $100 \mathrm{~W}$ for treatment durations viz., 'P1' (only vacuum, no plasma treatment), 'P2' (3 minute), 'P3' (6 minute), 'P4' (9 minute), 'P5' (12 minute), 'P6' (15 minute) and 'P7' (Control-Without treatment) during 2014. The seeds with different combination of treatments were evaluated for different seed crop characters. It has been observed that the plasma treatment of 12 minutes duration on A1 seeds could significantly improve days to first ripe fruit harvesting (103.25), plant height at final harvest $(161.19 \mathrm{~cm})$, number of ripe fruits per plant $(15)$ and ripe fruit yield per plant $(86.46 \mathrm{~g})$ as compared to control. The number of seeds per fruit (56.43), thousand seed weight $(55.91 \mathrm{~g})$, seed yield per plant $(47.55 \mathrm{~g})$, seed yield per plot $(1.50 \mathrm{~kg})$, seed yield per hectare $(27.34 \mathrm{q})$ and percent seed recovery (52.49) was significantly increased in one year old seed as compared to control. Therefore, our results show that cold plasma treatment has important application prospects for increasing seed yield of okra.
\end{abstract}

\section{Introduction}

Okra [Abelmoschus esculentus (L.) Moench] is a Dicotyledonae, belonging to the order Malvales, family Malvaceae and genus Abelmoschus (syn. Hibiscus). It is one of the most important vegetable crops cultivated in tropical, sub-tropical and warm temperate regions of the world. It is susceptible to frost, low temperature, water logging and drought conditions. Thompson and Kelley (1957) reported its origin is South Africa or Asia while Zeven and Zhukovsky (1975) believed that okra originated from India.

Okra is an annual crop propagated from seed, grown for its green tender fruits, which are cooked and consumed as a vegetable purpose in a variety of ways (Chattopadhyay et al., 2011). These fruits are rich in vitamins, calcium, potassium and other mineral matters (Camciuc et al., 1981). The mature okra seed 
is a good source of oil and protein (Oyelade et al., 2003) and has been known to have superior nutritional quality. Okra seed oil is rich in unsaturated fatty acids such as linoleic acid (Savello et al., 1980), which is essential for human nutrition. Its mature fruit and stems contain crude fibre, which is used in the paper industry. Its mucilage is suitable for medical application as a plasma replacement or blood volume expander. Hence, the quality of seed is of utmost importance to have good and uniform crop stand. However, when okra seeds are sown in early spring season, the prevailing low temperature hampers germination and vigour of seeds and ultimately the crop stand. Setubal et al., (1994) observed that the proportion of hard seeds significantly increased when the harvesting was delayed until senescence of the plant.

There are different seed enhancement technologies like coating, pelleting, priming etc which increases the moisture content of the seed during treatment. Here, a dry seed treatment i.e. plasma treatment is employed to increase the seed coat permeability without increasing the moisture content of seed. The method of Plasma seed treatment is a physicochemical method which has potential to improve germination yields and kill fungal spores carried on seed coats (Griesser et al., 2011). Cold plasma seed treatment is a modern eco-agricultural high technique that could increase crop yields (Jiafeng et al., 2014). A positive effect of low temperature plasma treatment on germination of various agricultural crops has been found (Sera et al., 2012). Today, plasma is used for varieties of industrial applications ranging from arc welding, metal hardening, nuclear fusion, creation of nano structure, functional polymer coating and change in surface hyrdrophilicity (Filatova et al., 2010). Hence, effect of cold plasma treatment on seed characters of okra seeds was studied.

\section{Materials and Methods}

Seeds of okra [Abelmoschus esculentus (L.) Moench] and cultivar P-8 were obtained from Dr. Y.S. Parmar university of Horticulture and Forestry Himachal Pradesh, India and were exposed to cold plasma treatment under the following parameters: Glow Discharge plasma of oxygen gas was used at a base pressure of $0.05 \mathrm{~m}$ bar, operating pressure of $0.2 \mathrm{~m}$ bar, voltage of $500 \mathrm{~V}$, current of $0.2 \mathrm{~A}$ and power of $100 \mathrm{~W}$ for treatment durations of $0,3,6,9$, 12 and 15 minutes. The plasma treatment was done at FCIPT (Facilitation Centre for Industrial Plasma Technologies), Institute for Plasma Research, Gandhinagar, Gujarat, India (An Institute under Department of Atomic Energy, GOI).

\section{Statistical analysis}

The field experiment was conducted during July, 2014 to Oct 2014 at Agricultural Research Farm, Dr Y. S. Parmar university of Horticulture and Forestry, Himachal Pradesh, India in Randomized Block Design (Factorial) with seven treatments replicated four times in each. The seeds of okra were sown as per the treatments in a plot having size of $2.0 \times 2.4 \mathrm{~m}^{2}$ i.e. $4.8 \mathrm{~m}^{2}$. FYM and fertilizers were applied as per package of practices for vegetable crops, Directorate of Extension Education, Dr. Y. S. Parmar University of Horticulture and Forestry, Nauni, Solan (HP) (FYM @ 100 quintal per ha, CAN @ 300 kg ha ${ }^{-1}$, SSP @ $315 \mathrm{~kg} \mathrm{ha}^{-1}$ and MOP @ $90 \mathrm{~kg} \mathrm{ha}^{-1}$ ).

\section{Results and Discussion}

\section{Days to first ripe fruit harvesting}

Early maturity is desirable trait which fetches good yield and returns to the growers. Days to first ripe fruit harvesting differed significantly between crop raised from one year and two year old seeds. The data presented in Table 1 
revealed that ripe fruits were ready in 109.07 days after sowing in crop raised from one year old seed and in 112.79 days in crop raised from two year old seeds. This is on account of delayed flowering in two year old seeds as a result of low initial seedling vigour and productivity status of aged seeds. Early first ripe fruit harvesting (105.38 days) was recorded in seed exposed to plasma for 12 minutes which was at par with 15 minutes (106.38 days) and 9 minutes (108.00 days) treatment, whereas late ripe fruit harvesting was recorded in vacuum (116.13 days) where no plasma treatment were given. However delayed first ripe fruit harvesting (116.38 days) was recorded in control seed where no plasma treatment was given. The probable reason for early maturity of plasma treated seed plants may be due to the fact that the plants of plasma treated seeds took fewer days to emerge and flower therefore it matured earlier than the plants of non plasma treated seeds. Plasma induces a range of biochemical changes in the seed that are required to start the germination process like, internal physiological change connected with seed hormonal activities and enzymes activation (Zivkovic et al., 2004 and Sera et al., 2008). Thus, upon seeding, plasma seeds can rapidly imbibe water and revive the seed metabolism, resulting in a higher germination rate and a reduction in the inherent physiological heterogeneity in germination (Spatenka et al., 2008).

\section{Plant height at final harvest}

Data recorded on plant height at final harvest after sowing as influenced by age of seed, plasma treatments and their interactions are presented in Table 1. Significantly higher plant height at final harvest after sowing $(136.37 \mathrm{~cm})$ was recorded with one year old seed as compared with two year old seed $(126.68 \mathrm{~cm})$.
The plant height at final harvest after sowing differed significantly due to different plasma exposure time on seed. Seed exposed to plasma for 12 minutes recorded highest plant height $(150.93 \mathrm{~cm})$ which was at par with 9 minutes $(137.04 \mathrm{~cm})$ treatment. The seed which was kept under vacuum and not exposed to plasma showed significantly low plant height $(122.00 \mathrm{~cm})$ compared to plasma treated seeds. The lowest plant height (119.90 $\mathrm{cm})$ was recorded in control i.e. untreated seeds.

The increased plant height at final harvest may be due to early emergence and also rapid cell division in meristematic region, number of cells and increase in cell elongation due to multiplication of various parts of the plant tissue, auxin metabolism, cell wall plasticity and permeability of cell membrane, increasing photosynthates, cell enlargement and rapid cell elongation (Sadavarthe and Gupta, 1963). The results are in conformity with the findings of Zhou et al., (2011) (Table 1). He reported increase in plant height in tomato seedlings and the possible reason may be the active oxygen particles that can penetrate into the seed, accelerate to decompose the inner nutriment of the seeds, reduce relative penetrability and improve the activities of the root of the tomato seedling.

\section{No of ripe fruits per plant}

Number of fruits per plant is a major seed yield contributing character as it is directly correlated to the seed yield and economic returns. Number of ripe fruits per plant differed significantly between crop raised from one year and crop raised from two year old seeds. The maximum number of ripe fruits per plant (13.61) was recorded in one year old seeds and lowest (11.61) in two year old seeds. It might be due to early emergence and less harvest duration was found in one year old seed. Seeds exposed to plasma for 12 
minutes recorded maximum number of ripe fruits per plant (14.50) which was at par with 9 minutes (13.88) treatment. The seed which was kept under vacuum and not exposed to plasma showed significantly minimum number of ripe fruits per plant (10.88) compared to plasma treated seed. While the minimum number of ripe fruits per plant (10.63) was recorded in control seed where no treatment were given. The increase in number of ripe fruits per plant with seed plasma may be due to early field emergence and harvest duration. The study of interaction effects between ageing and plasma treatments was found to be non-significant for fruit characters.

\section{Ripe fruit yield per plant}

Significant variations for fruit yield per plant were observed among all the plasma treatments. Seed exposed to plasma for 12 minutes recorded maximum ripe fruit yield per plant $(79.48 \mathrm{~g})$ which was at par with 9 minutes $(69.41 \mathrm{~g})$ treatment. The seed which was kept under vacuum and not exposed to plasma recorded minimum ripe fruit yield per plant $(43.00 \mathrm{~g})$ compared to plasma treated seeds. The minimum ripe fruit yield per plant $(42.02 \mathrm{~g})$ was recorded in control seed where no treatment was given.

Ripe fruit yield per plant is an important character that contributes to the fruit yield, seed yield and quality. Ripe fruit yield is correlated with more seed yield per plant. Highest ripe fruit weight $(65.01 \mathrm{~g})$ was obtained in one year old seed as compared to two year old seeds $(52.33 \mathrm{~g})$. This difference in relation to yield attributing character may be due to difference in vigour levels as reported by Funk et al., (1962) in maize. Maximum yield per plant (79.48 gm) was observed in seeds treated with 12 minutes plasma exposure which was at par with 9 minutes $(69.41 \mathrm{~g})$ treatment. The seed which was kept under vacuum and not exposed to plasma recorded minimum ripe fruit yield per plant $(43.00 \mathrm{~g})$ compared to plasma treated seeds. The minimum ripe fruit yield per plant $(42.02 \mathrm{~g})$ was recorded in control seed where no treatment was given. The increase in fruit yield may be due to early emergence, higher total emergence, more number of flowers per plant, increase in fruit weight and more number of fruits per plant. The results are in conformity with Krapivina et al., (1994), Zhou-Wen et al., (2009) and Jiang et al., (2014). They reported increase in yield due to seed plasma in soybean, tomato and wheat, respectively. Interaction effects between aged and plasma treatments were found to be nonsignificant for fruit yield characters.

\section{Number of seeds per fruit}

Number of seeds per fruit is one of the important characters contributing to the seed yield. The number of seeds per fruit after harvesting is influenced by age of seed, plasma treatments and their interactions showed in Table 3. Significantly higher number of seeds per fruit after harvesting (49.91) was recorded in one year old seed as compared with two year old seed (48.94).

A significant improvement in number of seeds per fruit was observed due to different exposure of plasma treatments. Seed exposed to plasma for 12 minutes recorded highest number of seeds per fruit (55.22) which was at par with 15 minutes (50.51) and 9 minutes (52.78) treatment. The seed which was kept under vacuum and not exposed to plasma showed significantly low number of seeds per fruit (45.73) compared to plasma treated seeds. The lowest number of seeds per fruit (44.13) was recorded in control i.e. untreated seed. The increase in number of seeds per fruit may be due to may be due to early emergence, more number of flowers per plant, increase in fruit weight and more number of fruits per 
plant. The results are in conformity with Krapivina et al., (1994), Zhou-Wen et al., (2009) and Jiang et al., (2014). They reported increase in yield due to seed plasma in soybean, tomato and wheat, respectively.

\section{Thousand seed weight}

Thousand seed weight or test weight is an important parameter governing the boldness of the seed and ultimately the quality. Higher 1000 seed weight is directly correlated to seed vigour which is one of the most important characters in seed studies. Maximum 1000 seed weight $(51.78 \mathrm{~g})$ was obtained in one year old seed, whereas, minimum 1000 seed weight $(50.13 \mathrm{~g})$ was obtained in two year old seeds. Analysis of data revealed that exposure time of plasma to the seed significantly influenced the thousand seed weight. Higher thousand seed weight was, however, observed in the seed exposed to plasma for 12 minutes $(54.51 \mathrm{~g})$, which was at par with 15 minutes exposure time $(51.91 \mathrm{~g}), 9$ minutes $(52.39 \mathrm{~g})$ and 6 minutes $(51.66 \mathrm{~g})$ treatment. The seed which was kept under vacuum and not exposed to plasma showed significantly lower thousand seed weight (48.36 g) compared to plasma treated seeds. The lowest thousand seed weight ( $48.15 \mathrm{~g}$ ) was observed in control seed where no plasma treatment was given.This may be due to the bigger and good quality fruits resulting in bold seeds, which ultimately increases the seed weight.

Higher thousand seed weight means bolder seeds and hence more will be the seed vigour which is one of the most important characters in seed studies. The studies revealed that plasma treatment had a significant effect on thousand seed weight. This may be due to the bigger and good quality fruits resulting in bold seeds, which ultimately increase the seed weight (Jiang et al., 2014). Reason may be removal of thin lipid layer due to exposure of seeds to plasma treatment, which makes the seed water repellant thereby improving the germination and seed quality (Sera et al., 2012). It also enhances the seed surface enrichment and inactivation of seed pathogens. It is a cost effective and ecologically sustainable method.

\section{Seed yield per plant}

Data pertaining to seed yield per plant as influenced by age of seed, plasma treatments and their interactions are presented in Table 4. The maximum seed yield per plant (35.76 g) was observed in one year old seeds and the minimum seed yield per plant (28.78 g) was recorded in two year old seeds.

While comparing the exposure time of plasma to the seed, it significantly influenced seed yield per plant. Seed exposed to plasma for 12 minutes recorded maximum seed yield per plant $(43.71 \mathrm{~g})$ which was at par with 9 minutes $(38.17 \mathrm{~g})$ treatment. The seed which was kept under vacuum and not exposed to plasma recorded minimum seed yield per plant $(23.65 \mathrm{~g})$ compared to plasma treated seeds. The minimum seed yield per plant (23.11 g) was recorded in control seed where no vacuum and no plasma treatment were given.

The reason might be due to more number of fruits per plant, highest fruit weight, maximum fruit size and maximum ripe fruit yield recorded in 12 minutes plasma treatment and these factors resulted in maximum seed yield. The study of interaction effects between ageing and plasma treatments was found to be non-significant for seed yield characters.

\section{Seed yield per plot}

The result on seed yield per plot as influenced by age of seed, plasma treatments and their interactions are presented in Table 4. The maximum seed yield per plot $(1.19 \mathrm{~kg})$ was observed in one year old seeds and the minimum seed yield per plot $(0.93 \mathrm{~kg})$ was recorded in two year old seeds. 
Table.1 Effect of seed age and plasma treatment on days to first ripe fruit harvesting and plant height at final harvest in okra

\begin{tabular}{|c|c|c|c|c|c|c|c|}
\hline $\begin{array}{c}\text { Plasma } \\
\text { Treatment }\end{array}$ & \multicolumn{4}{|c|}{ Days to first ripe fruit } & \multicolumn{3}{|c|}{$\begin{array}{l}\text { Plant height at final harvest } \\
\qquad(\mathrm{cm})\end{array}$} \\
\hline Durations & \multicolumn{4}{|c|}{ harvesting } & & & \\
\hline (P) & \multirow{2}{*}{$\begin{array}{l}\text { One } \\
\text { Year } \\
\text { Seed } \\
\left(\mathbf{A}_{1}\right)\end{array}$} & \multirow{2}{*}{\multicolumn{2}{|c|}{ Two Year Seed $\left(A_{2}\right)$}} & Mean & \multirow{2}{*}{$\begin{array}{c}\text { One } \\
\text { Year } \\
\text { Seed } \\
\left(\mathbf{A}_{1}\right)\end{array}$} & \multirow{2}{*}{$\begin{array}{c}\text { Two } \\
\text { Year } \\
\text { Seed } \\
\left(\mathbf{A}_{2}\right)\end{array}$} & \multirow{2}{*}{$\begin{array}{c}\text { Mean } \\
(\mathbf{P})\end{array}$} \\
\hline & & & & (P) & & & \\
\hline Vacuum & 114.25 & \multicolumn{2}{|c|}{118.00} & $116.13^{d}$ & 125.95 & 118.05 & $122.00^{\mathrm{ab}}$ \\
\hline 3 minutes & 111.50 & \multicolumn{2}{|c|}{115.50} & $113.50^{\text {cd }}$ & 132.5 & 120.95 & $126.73^{a b}$ \\
\hline 6 minutes & 108.75 & \multicolumn{2}{|c|}{112.75} & $110.75^{b c}$ & 134.15 & 128.70 & $131.43^{a b}$ \\
\hline 9 minutes & 106.00 & \multicolumn{2}{|c|}{110.00} & $108.00^{\mathrm{ab}}$ & 141.48 & 132.60 & $137.04^{\mathrm{bc}}$ \\
\hline 12 minutes & 103.25 & \multicolumn{2}{|c|}{107.50} & $105.38^{\mathrm{a}}$ & 161.19 & 140.66 & $150.93^{c}$ \\
\hline 15 minutes & 104.75 & \multicolumn{2}{|c|}{108.00} & $106.38^{a}$ & 135.83 & 129.50 & $132.66^{\mathrm{ab}}$ \\
\hline Control & 115.00 & \multicolumn{2}{|c|}{117.75} & $116.38^{d}$ & 123.53 & 116.28 & $119.90^{\mathrm{a}}$ \\
\hline $\begin{array}{l}\text { (untreated) } \\
\text { Mean (A) }\end{array}$ & $109.07^{A}$ & \multicolumn{2}{|c|}{$112.79^{B}$} & & $136.37^{\mathrm{A}}$ & $126.68^{B}$ & \\
\hline & $\mathrm{CD}_{0.05} \quad(\mathrm{~A})$ & & 2.28 & \multicolumn{4}{|c|}{8.74} \\
\hline & \multicolumn{2}{|c|}{ (P) } & 4.27 & & \multicolumn{2}{|c|}{16.35} & \\
\hline & \multicolumn{2}{|c|}{$(\mathrm{AxP})$} & NS & & \multicolumn{2}{|c|}{ NS } & \\
\hline
\end{tabular}

Table.2 Effect of seed age and plasma treatment on number of ripe fruits per plant and ripe fruit yield per plant in okra

\begin{tabular}{|l|c|c|c|c|c|c|}
\hline $\begin{array}{c}\text { Plasma } \\
\text { Treatment }\end{array}$ & \multicolumn{3}{|c|}{ Number of ripe fruits per plant } & \multicolumn{3}{c|}{ Ripe fruit yield per plant } \\
Durations
\end{tabular}


Table.3 Effect of seed age and plasma treatment on number of seeds per fruit and thousand seed weight in okra

\begin{tabular}{|c|c|c|c|c|c|c|c|}
\hline \multirow{4}{*}{$\begin{array}{c}\text { Plasma Treatment } \\
\text { Durations } \\
(\mathrm{P})\end{array}$} & \multicolumn{4}{|c|}{ Number of seeds per fruit } & \multicolumn{3}{|c|}{ Thousand seed weight } \\
\hline & \multirow{3}{*}{$\begin{array}{l}\text { One Year } \\
\text { Seed }\left(A_{1}\right)\end{array}$} & & & & & (g) & \\
\hline & & \multirow{2}{*}{\multicolumn{2}{|c|}{ Two Year Seed $\left(A_{2}\right)$}} & Mean & \multirow{2}{*}{$\begin{array}{l}\text { One Year } \\
\text { Seed }\left(\mathbf{A}_{1}\right)\end{array}$} & \multirow{2}{*}{$\begin{array}{l}\text { Two Year } \\
\text { Seed }\left(A_{2}\right)\end{array}$} & \multirow{2}{*}{$\begin{array}{c}\text { Mean } \\
(\mathbf{P})\end{array}$} \\
\hline & & & & (P) & & & \\
\hline Vacuum & 45.05 & \multicolumn{2}{|l|}{46.41} & $45.73^{\mathrm{ab}}$ & 49.07 & 47.64 & $48.36^{a}$ \\
\hline 3 minutes & 47.69 & \multicolumn{2}{|l|}{48.07} & $47.88^{\mathrm{abc}}$ & 50.57 & 48.82 & $49.70^{a b}$ \\
\hline 6 minutes & 50.27 & \multicolumn{2}{|l|}{49.21} & $49.74^{b c}$ & 52.53 & 50.77 & $51.66^{b c}$ \\
\hline 9 minutes & 53.65 & \multicolumn{2}{|l|}{51.91} & $52.78^{\mathrm{cd}}$ & 53.55 & 51.21 & $52.39^{b c}$ \\
\hline 12 minutes & 56.43 & \multicolumn{2}{|l|}{54.01} & $55.22^{d}$ & 55.91 & 53.10 & $54.51^{c}$ \\
\hline 15 minutes & 52.07 & \multicolumn{2}{|l|}{48.95} & $50.51^{\text {bed }}$ & 51.94 & 51.88 & $51.91^{\text {bc }}$ \\
\hline Control (untreated) & 44.25 & \multicolumn{2}{|l|}{44.01} & $44.13^{a}$ & 48.85 & 47.44 & $48.15^{a}$ \\
\hline Mean (A) & 49.91 & \multicolumn{2}{|l|}{48.94} & & $51.78^{A}$ & $50.13^{B}$ & \\
\hline & $\mathrm{CD}_{0.05}$ & & NS & & \multicolumn{3}{|c|}{1.55} \\
\hline & (P) & & 5.39 & & \multicolumn{3}{|c|}{2.91} \\
\hline & $(\mathrm{AxP})$ & & NS & & \multicolumn{3}{|c|}{ NS } \\
\hline
\end{tabular}

Table.4 Effect of seed age and plasma treatment on seed yield per plant and seed yield per plot in okra

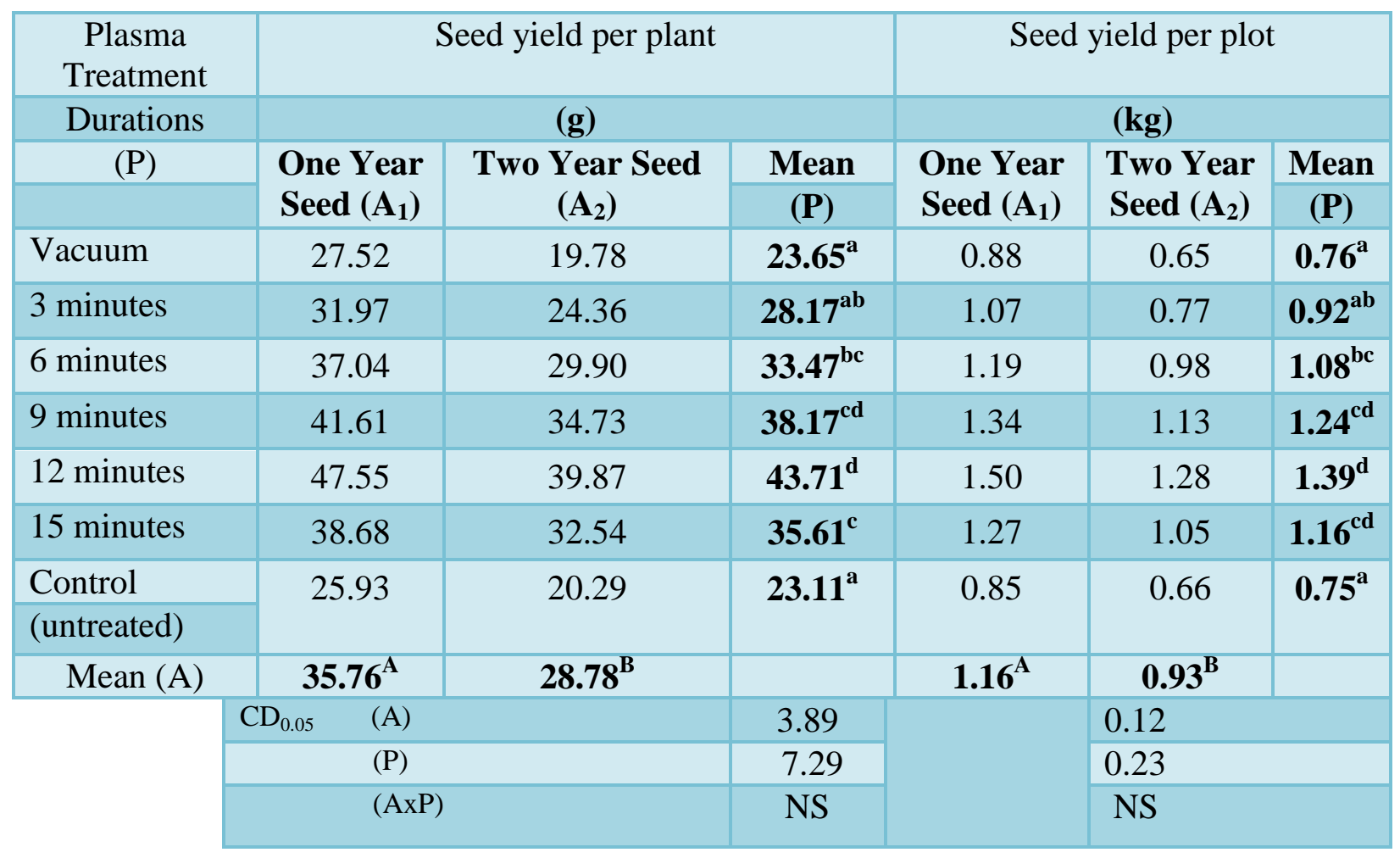


Table.5 Effect of seed age and plasma treatment on seed yield per hectare and percent seed recovery in okra

\begin{tabular}{|c|c|c|c|c|c|c|}
\hline Plasma & \multicolumn{3}{|c|}{ Seed yield per hectare $(q)$} & \multicolumn{3}{|c|}{ Percent seed recovery } \\
\hline Durations & One Year & Two Year & Mean & One Year & Two Year & Mean \\
\hline$(\mathrm{P})$ & Seed $\left(\mathbf{A}_{1}\right)$ & Seed $\left(\mathbf{A}_{2}\right)$ & (P) & Seed $\left(A_{1}\right)$ & Seed $\left(\mathbf{A}_{2}\right)$ & (P) \\
\hline Vacuum & 15.92 & 11.78 & $13.85^{\mathrm{a}}$ & 52.17 & 51.66 & $51.92^{\mathrm{a}}$ \\
\hline 3 minutes & 19.49 & 14.00 & $16.75^{\mathrm{ab}}$ & 52.76 & 51.78 & $52.27^{a b}$ \\
\hline 6 minutes & 21.58 & 17.84 & $19.71^{b c}$ & 52.83 & 52.35 & $52.59^{b c}$ \\
\hline 9 minutes & 24.35 & 20.62 & $22.49^{\mathrm{cd}}$ & 53.26 & 52.89 & $53.08^{\mathrm{cd}}$ \\
\hline 12 minutes & 27.34 & 23.18 & $25.26^{d}$ & 53.49 & 53.20 & $53.35^{d}$ \\
\hline 15 minutes & 23.03 & 19.10 & $21.06^{\mathrm{cd}}$ & 53.15 & 52.34 & $52.75^{b c}$ \\
\hline $\begin{array}{l}\text { Control } \\
\text { (untreated) }\end{array}$ & 15.36 & 12.03 & $13.70^{a}$ & 52.35 & 51.32 & $51.84^{a}$ \\
\hline Mean (A) & $21.01^{\mathrm{A}}$ & $16.94^{\mathrm{B}}$ & & $52.86^{\mathrm{A}}$ & $52.22^{\mathrm{B}}$ & \\
\hline $\begin{array}{ll}\mathrm{CD}_{0.05} & (\mathrm{~A}) \\
& (\mathbf{P}) \\
& (\mathrm{AxP})\end{array}$ & & $\begin{array}{l}2.28 \\
4.26 \\
\mathrm{NS}\end{array}$ & & & & \\
\hline
\end{tabular}

A significant improvement in seed yield per plot was observed due to different exposure of plasma over control. Seed exposed to plasma for 12 minutes recorded maximum seed yield per plot $(1.39 \mathrm{~kg})$ which was at par with 9 minutes $(1.24 \mathrm{~kg})$ and 15 minutes $(1.16 \mathrm{~kg})$ treatment. The seed which was kept under vacuum and not exposed to plasma recorded minimum seed yield per plot $(0.76 \mathrm{~kg})$ compared to plasma treated seeds. While the minimum seed yield per plot $(0.75 \mathrm{~kg})$ was recorded in control seed where no vacuum and no plasma treatment were given.

It might be due to more number of fruits per plant, highest fruit weight, maximum fruit size and maximum ripe fruit yield recorded in 12 minutes plasma treatment and these factors resulted in maximum seed yield.

\section{Seed yield per hectare}

Data on seed yield per hectare is influenced by age of seed, plasma treatments and their interactions are presented in Table 5. The maximum seed yield per hectare (21.01 q) was observed in one year old seeds and the minimum seed yield per hectare (16.94 q) was recorded in two year old seeds.

Significant influenced in seed yield per hectare as affected by exposure time of plasma to the seed. Seed exposed to plasma for 12 minutes recorded maximum seed yield per hectare $(25.26 \mathrm{q})$ which was at par with 9 minutes (22.49 q) and 15 minutes (21.06 q) treatment. The seed which was kept under vacuum and not exposed to plasma recorded minimum seed yield per hectare (13.85 q) compared to plasma treated seeds. The minimum seed yield per hectare (13.70 q) was observed in control i.e. untreated seed.

The reason might be due to more number of fruits per plant, highest fruit weight, maximum fruit size and maximum ripe fruit yield recorded in 12 minutes plasma treatment and these factors resulted in maximum seed 
yield. The study of interaction effects between ageing and plasma treatments was found to be non-significant for seed yield characters.

\section{Percent seed recovery}

The percent seed recovery is one of the important parameters that decides the final seed yield of the crop. Maximum seed recovery $(52.86 \%)$ was obtained with crop raised from one year old seed and the minimum seed recovery $(52.22 \%)$ was obtained in crop raised from two year old seeds. Seed exposed to plasma for 12 minutes recorded highest percent seed recovery $(53.35$ $\%)$ which was at par with 9 minutes $(53.08$ $\%)$ treatment. The seed which was kept under vacuum and not exposed to plasma showed significantly lower percent seed recovery (51.92\%) compared to plasma treated seeds. The lowest percent seed recovery $(51.84 \%)$ was recorded in control seed where no treatment was given.

This may be due to more number of fruits per plant, more number of seeds per fruit and high 1000 seed weight. Interaction effects between aged and plasma treatments were found to be non-significant for seed characters.

\section{Acknowledgements}

The authors thank FCIPT Institute for Plasma Research, Gandhinagar, Gujarat, India for the seed treatment and Dr YS Parmar, University of Horticulture and Forestry, Solan, Department of Seed Science and Technology for providing all the facilities to perform the study.

\section{References}

Camciuc, M, Bessifre, J.M, Vilarem, G. and Gaset, A. 1981. Volatile components in okra seed coat. Phytochem., 48: 311315 .
Chattopadhyay, A., Dutta, S. and Chatterjee, S. (2011). Seed yield and quality of okra as influenced by sowing dates. Afr. J. Biotec., 10(28): 5461-5467.

Filatova, I., Azharnok, V., Gorodetskaya, E., Shedikova, O., Shik, A., 2010. Plasma radiowave stimulation of plant seeds germination and inactivation of pathogenic microorganisms. 2010. International Symposium on Plasma Chemistry conference.

Griesser, S.S., Prakas, S., Griesser, H.J., 2011. Plasma discharge treatment for improved germination of seeds and killing of fungal spores on seed coats. Final project report to the Australian Flora Foundation. Ian Wark Research Institute, University of South Australia, Mawson Lakes, SA 5095.

Jiang Jiafeng, He Xin, Li Ling, Li Jiangang, Shao Hanliang, Xu Qilai, Ye Renhong, and Dong Yuanhua. 2014. Effect of cold plasma treatment on seed germination and growth of wheat. Plasma Science and Technology 16(1): 54-57

Krapivina S A, Alexander K F, Tatiana N L and Andrei B. 1994. Gas plasma treatment of plant seeds. United States Patent. pp. 54-56

Oyelade, O.J, Ade-Omowaye, B.I.O. and Adeomi, V.F. (2003). Influence of variety on protein, fat contents and some physical characteristics of okra seeds. Journal of Food Engineering. 57. 111-114.

Sadavarte KT and Gupta PK, Effect of seed treatment with plant growth regulators on germination, growth and yield of brinjal. The Punjab Horticulture Journal, 1963, 2: 195-199.

Savello, P., F.W. Martin and J.M. Mill. 1980. Nutritional composition of okra seed meal. Agri. Food Chem. 28: 11631166.

Sera B, Stranak V, Sery M, Tichy M and 
Spatenka P. 2008. Germination of Chenopodium album in response to microwave plasma treatment. Plasma Science and Technology 10(4): 506-510

Sera, B., Gajdova, I., Cernak, M., Gavril, B., Hnatiuc, E., Kovacik, D., Kriha, V., Slama. J., Sery, M., Spatenka, P., 2012. How various plasma sources may affect seed germination and growth. IEEE Plasma Science 39(7), 1365-1369.

Setubal, J.W., Zanin, A.C.W., Nakagawa, J., 1994. Efeitos de metodos de colheita e da localizacao dos frutos na planta sobre a ocorrencia de sementes duras em quiabeiro (Abelmoschus esculenthus (L.) Moench). Sci Agric 51, 490-493.

Spatenka P, Stranak V, Sery M, Tichy M and Sera B. 2008. Germination of Chenopodium album in response to microwave plasma treatment. Plasma Science and Technology 10(4): 506-510

Thompson, C.H. and Kelley, C.W. (1957). Vegetable crops. McGraw Hill Book Co., Inc., USA

Zeven, A.C. and Zhukovsky, P.M. (1975).
Dictionary of cultivated plants and their Centres of Diversity: excluding ornamentals, forests trees and lower plants. Centre for Agric. Pub. And Doc. (PUDOC), Wageningen, The Netherlands, 219.

Zhou Z, Huang Y, Yang S and Chen W, Introduction of a new atmospheric pressure plasma device and application on tomato seeds. Agricultural Sciences, 2011, 2(1): 23-27.

Zhou-Wen Zhou, Yan-Fen Huang, Si-Ze Yang and Ming-Sen Deng. 2009. Effects of plasma treatment on yield and quality of Hongza (tomato) 10 seeds. Guizhou-Agricultural-Sciences 12: 5861

Zivkovic S, Puac N, Giba Z, Grubisic D and Petrovic Z. 2004. The stimulatory effect of non-equilibrium (low temperature) air plasma pre-treatment on lightinduced germination of Paulownia tomentosa seeds. Seed Science and Technology 32(3): 693-701

\section{How to cite this article:}

Ravinder Kumar, Ashok K. Thakur, Amit Vikram, A. Vaid and Rane, R. 2018. Effect of Plasma Treatment on Seed Crop Characters of Okra [Abelmoschus esculentus (L.) under Field Conditions. Int.J.Curr.Microbiol.App.Sci. 7(12): 967-976.

doi: https://doi.org/10.20546/ijcmas.2018.712.120 